Vol. 4, Issue.6, Nov-Dec 2021, page no. 336-346

To cite this article: Yuanita Dwi Hapsari, Trisni Utami and Mahendra Wijaya (2021). SOCIAL CAPITAL OF THE RIVER TUBING TOURISM COMMUNITY IN OPTIMIZING THE MANAGEMENT OF THE PUSUR SUBWATERSHED, KLATEN REGENCY, International Journal of Education and Social Science Research (IJESSR) 4 (6): $336-346$

\title{
SOCIAL CAPITAL OF THE RIVER TUBING TOURISM COMMUNITY IN OPTIMIZING THE MANAGEMENT OF THE PUSUR SUB-WATERSHED, KLATEN REGENCY
}

\author{
Yuanita Dwi Hapsari ${ }^{1}$, Trisni Utami ${ }^{2}$ and Mahendra Wijaya ${ }^{3}$ \\ ${ }^{1}$ Master's Degree Program of Sociology, Faculty of Social and Political Sciences \\ Sebelas Maret University, Surakarta, Indonesia \\ ${ }^{2}$ Sociology Department, Faculty of Social and Political Sciences \\ Sebelas Maret University, Surakarta, Indonesia \\ ${ }^{3}$ Sociology Department, Faculty of Social and Political Sciences \\ Sebelas Maret University, Surakarta, Indonesia
}

DOI: http://dx.doi.org/10.37500/IJESSR.2021.4625

\begin{abstract}
Klaten Regency is an area known to have water tourism potential. River Tubing is a water tourism object that makes the Pusur sub-watershed an attraction. This tour was developed by several community groups who are members of the River Tubing Pusur Adventure (RTPA) and Watu Kapu Community. The objectives of this study 1) identify the strategies of the RTPA and Watu Kapu communities in the development of tubing tourism in the Pusur sub-watershed; 2) analyze the social capital used by the RTPA and Watu Kapu communities in developing tubing tourism in the Pusur subwatershed. The research method used is qualitative with a descriptive analytical approach. The results of the study are: 1) the strategies of the RTPA and Watu Kapu communities in developing tubing tourism, including building networks with NGOs, the Government, companies, and communities; provide attractive tour packages; take action to clean the river so that the cleanliness of the river is maintained; collaborating with the Pusur Institute 2) there is a mobilization of social capital in the development of the Pusur sub-watershed as a tubing tourism object and improving the community's economy. Social capital used in the development of tubing tourism is participation in a network, trust, and social norms.
\end{abstract}

KEYWORDS: social capital, community, tourism, watershed

\section{INTRODUCTION}

Two-thirds of Indonesia's territory is territorial waters. This is the reason Indonesia is included in the category of 10 countries rich in water [1]. We can see the potential of the waters in Indonesia from the 
number of river distributions. Almost every island in Indonesia has a river that divides big cities, even its flow can divide large islands [2].

As part of the ecosystem, rivers must be managed in an integrated and comprehensive manner. All aspects, parties, and disciplines must be interconnected. River management must also have a broad scope, covering upstream to downstream [3]. Many benefits can be obtained if the potential of river ecosystems is managed properly, one of which is the development of river tourism. The river ecosystem has the potential to be developed into a tourist attraction that has an ecotourism attraction. Besides being able to create jobs, of course also as a driver of river conservation programs [4]. In principle, by developing ecotourism, it is hoped that the economic benefits derived from tourism can go hand in hand with efforts to protect the quality of natural resources. [5]

Klaten Regency is an area known to have diverse tourism potential. Each sub-district has a unique type of tourism potential and can be categorized into several types of tourism objects, such as water tourism, ancient temples, tombs/religious tourism, natural scenery, and museums. The water tourism sector shows significant development from year to year, where the number continues to increase. In 2010 2013 has 67 attractions. In 2014-2016 there was an increase so that the number of tourism objects became 73. A significant increase occurred in 2017 with 106 water attractions. Polanharjo sub-district is the sub-district that has the most water tourism objects [6]

Based on data from BPS Klaten Regency, Polanharjo District is the sub-district that has the most water tourism objects. Not only is it famous for its umbulnya, but in Polanharjo District, many swimming pools have also been developed to tour along the river. The famous river tours are the Pusur Adventure River Tubing Tour (RTPA) and Watu Kapu which were developed in 2016. This tour utilizes the Pusur sub-watershed flow as a visitor attraction [7].

The Pusur sub-watershed stretches from upstream to downstream. The upstream is located in the Musuk Boyolali District and the downstream is in the Juwiring and Delanggu Districts. The middle part stretches from Polanharjo and Tulung sub-districts [8].

Efforts to make the Pusur River flow as a tourist attraction are not instant. The reason is, before developing as it is now, the Pusur River was only interpreted as a backyard for the people in Tulung and Polanharjo Districts [9]. The notion that the river is a backyard arises as a result of the people's habit of throwing dirt and garbage directly into the river [10].

The development of tubing tourism in the Pusur sub-watershed was initially managed by 10 youths from Jragan Village, Polanharjo Sub-district who have a hobby of adventuring and cleaning rivers using used tires. Departing from the hobby of adventure as well as clean rivers owned by community members, making Sungai Pusur become one of the tubing tourist attractions that attracts many tourists. 
The role of the community is very important in the occurrence of changes in the community environment both socially and physically. In the development process, the role of the community is a very important point. The community is a party that can understand the opportunities and obstacles in its territory, and no one knows or is interested in the affairs of a region other than the community itself [11].

This article was written with the aim of identifying the strategies of the RTPA and Watu Kapu communities in developing tubing tourism in the Pusur sub-watershed and analyzing the social capital used by the RTPA and Watu Kapu communities in developing tubing tourism in the Pusur subwatershed. Robert Putnam's social capital theory was used to analyze the research findings. Basically, when social capital consisting of networks, trust, reciprocal relationships, social norms and proactive actions can be properly mobilized by the community, the potential for tubing tourism in Pusur Subwatershed will be able to continue to grow.

\section{METHODS}

The method used in this article is qualitative with a descriptive analytical approach. By using qualitative research methods, researchers collect and analyze data in the form of words (oral and written) and human actions [12]. The analytical descriptive approach was chosen because this approach aims to describe an object through the collected data and then draw general conclusions [13]. The reason for choosing an analytical descriptive approach is because this article will analyze in depth the strategies of the RTPA and Watu Kapu communities in the development of tubing tourism in the Pusur Sub-watershed and analyze the social capital used by the RTPA and Watu Kapu communities in developing tubing tourism in the Pusur Sub-watershed.

The research was conducted at the River Tubing Pusur Adventure (RTPA) and Watu Kapu attractions located in the Pusur sub-watershed, Jragan Hamlet, Wangen Village, Polanharjo District, Klaten Regency. The reason for choosing the research location is because River Tubing Pusur Adventure (RTPA) and Wau Kapu Tourism are pioneers in tourism development along the Pusur sub-watershed. In addition, the management of tubing tourism objects is carried out by the community directly.

The research data obtained through interviews with informants and literature study. After the data is collected, the data analysis process is carried out using the analytical model from Miles and Huberman which consists of the stages of data reduction, data presentation and drawing conclusions.

\section{RESULTS AND DISCUSSION}

Administratively, the Pusur sub-watershed flows from the area in Boyolali Regency as the upstream part and Klaten Regency as the middle and downstream part. Each region from upstream, middle, and 
downstream has a different character, so that the conservation and management strategies applied are also different in each region.

The characteristics of the upstream area of the Pusur sub-watershed have a porous contour so that it is prone to landslides. In addition, the upstream area as a recharge area also faces problems with forest and land degradation as well as limited access to clean water. The central region has problem characteristics in terms of public awareness of waste, water management both in quality and quantity as well as potential conflicts with water users. The downstream area has the characteristics of a lack of water availability, especially during the third planting season or during the dry season. On the basis of these differences in characteristics, the programs aimed at the management of the Pusur subwatershed vary according to the characteristics of the region. Before developing as it is now, the Pusur River was only interpreted as a backyard by the people who live around it.

The Pusur sub-watershed actually has strategic potential in water management because it has a source of water that can be used for drinking water, irrigation, fisheries, industry, and tourism [14]. The central region is an area that is awarded a high-water discharge because in the central region there are Cokro and Sigedang springs so that the central region is widely developed for river tourism or river tubing.

Initially, the emergence of river tubing tourism was initiated by a number of youths from Dusun Jragan who had a hobby of adventuring in the river to clean the Pusur River using old tires. This idea received a good response from the government at the village and sub-district levels as well as PT Tirta Investama (Aqua). PT Tirta Investama (Aqua) responded by providing several sets of buoys as a means of supporting tubing tourism activities. This youth activity brought the Pusur River into a cleaner river and was widely known by the public for offering tubing tours. The public's interest in the presence of this tubing tour, the Pusur River is quite high. Tubing tour operators continue to grow. There are at least 5 (five) tubing tour managers, both those managed by the government, youth organizations, individuals, and communities

This section will describe the strategy of the River Tubing Pusur Adventure (RTPA) and Watu Kapu communities in the development of tubing tourism in the Pusur Sub-watershed and analyze the social capital used by the RTPA and Watu Kapu communities.

\subsection{RTPA and Watu Kapu community strategies for tubing tourism development}

\section{a. Build networks with government, NGOs, companies, and communities}

In principle, in carrying out various activities or programs whose targets involve many people, the contribution of several elements or parties is an absolute must-have. The tourism development is no exception. Stakeholders need to understand their roles and functions so that tourism development in an area can be realized and carried out properly [15]. Tourism development activities are basically 
activities that require the participation of various parties to realize tourism that is able to improve the economy of the surrounding community.

Initially, before developing as it is now, the existence of Pusur River tubing tourism was initiated by this river conservation activity initiated by several youths who had the awareness to create a better river environment. It turns out that their activities are in line with the Corporate Social Responsibility (CSR) program of PT Tirta Investama (Aqua). For this reason, PT Tirta Invertama provides life jackets and helmets as initial capital to build tourism

Adventure activities while cleaning the river flow that were uploaded on social media turned out to attract the attention of the public to enjoy the beauty of the Pusur River. The emergence of all activities to clean the river flow has become a motivation for the surrounding villages to be able to develop Pusur River tubing tourism. Tourism activities and river conservation are enough to have an impact on changes in the environment around the river. Changes in the environment around the river are also supported by the CSR program of PT Tirta Invertama which in its implementation collaborates with several NGOs such as Gita Pertiwi, LPTP Surakarta and LESTARI to facilitate activities aimed at conservation in the Pusur River.

Activities to support the preservation of the Pusur River, such as in Mundu Village, Tulung District, which is adjacent to the Pusur River, there is a biogas production program. This is motivated by the condition of the community where the majority of the people have dairy cows. But the problem is how to dispose of cow dung, they still use the river as a dumping ground. To reduce the pollution of the Pusur River due to cow dung pollution, there was an initiative from youth, LPTP Surakarta, and CSR PT Tirta Investama (Aqua) in 2015 to utilize cow dung waste as biogas. Cow dung which was initially only dumped in the Pusur River can now be used for gas needs for housewives

Furthermore, in the area around the Pusur River, especially in Polanharjo District, there is the "Bank Sampah" (waste bank) called Semut Harjo. Semut Harjo is a waste bank that houses 18 village-level waste banks. The initiation of this waste bank program was formed from the initiation of a CSR program from PT Tirta Investama (Aqua) in collaboration with the NGO Lestari as a program facilitator. Household waste which is usually directly dumped into the river is sorted into categories suitable for sale, suitable for creation and disposal. Garbage that has been sorted based on these categories is then created into products that have aesthetic value and selling points such as bags, laptop cases, wallets, tissue holders and others. The sales turnover resulting from the creation of waste by the Waste Bank in Polanharjo District can reach up to tens of millions of rupiah. For this reason, the existence of the Waste Bank, apart from being a strategy to suppress waste disposal into rivers, can also be used by mothers as additional economic income. 
Basically, the central area of the Pusur sub-watershed is not only used for tourism but also for agricultural activities. Agricultural activities must use chemicals to ward off pests that interfere with agricultural productivity. To minimize the disposal of chemical residues from agricultural activities into the Pusur River, in Karanglo Village, Polanharjo District, an agricultural clinic or previously known as an agricultural laboratory was established. This agricultural clinic program is also supported by CSR from PT Tirta Investama (Aqua) in collaboration with the NGO Gita Pertiwi as program facilitator. The main objective of establishing this agricultural line is to increase the knowledge capacity and skills of farmers in managing agricultural land on the basis of environmentally friendly agricultural practices. Agricultural clinics have developed the cultivation of owls as natural predators to ward off agricultural pests. Of course, this indirectly contributes to securing the Pusur River from pollution caused by agricultural chemical residues.

The conservation process in the Pusur River itself is basically different between the upstream, middle and downstream areas. To avoid partial conservation activities, the Pusur Institute was formed. The Pusur Institute was inaugurated by the Regent of Klaten on December 12, 2016 to accommodate all forms of activities from several communities that care about pusur and to create collaborative relationships in the preservation of the Pusur River. The management of the Pusur Institute comes from the upstream, middle and downstream communities. In carrying out its activities, the Pusur Institute acts as a collective awareness medium to form an integrated Pusur Sub-watershed management activity. Integrative management certainly leads to mutually supportive efforts for various activities along the Pusur sub-watershed.

The development of tubing tourism in RTPA and Watu Kapu is also supported by the role of the government. The government, especially the Polanharjo sub-district government, provides support with the allocation of village funds for the development of tubing tourism. The existing village funds are used to improve infrastructure that supports tourism.

\section{b. Provide attractive tour packages.}

To be able to feel the sensation of tubing on the Pusur River, the RTPA Community and Watu Kapu provide 2 tour packages, namely the package per person for Rp. 70,000 and the package per person for Rp. 50,000. The tour packages provided are complete, starting from a guide, tubing equipment, photos, and also food and drinks. Provision of food and drinks for visitors to the tubing pusur tour, involves the community, especially women. In addition, for bathing and rinsing, the community also rents out bathrooms for rinsing after visitors enjoy tubing on the Pusur River. From this activity, the community can get additional income of up to millions of rupiah, especially if there is a long holiday and visitors at the pusur tubing are busy with visitors.

Tubing tour rates are set on the basis of a joint decision between 5 (five) tour managers. This is done to avoid conflicts that arise from business competition from the existence of this tourism. This same 
rate is also used so that there is no visitor overload in one of the tour operators. Visitor overload will certainly affect the safety of visitors' Standard Operating Procedures (SOP).

To attract visitors, the tourism management community also provides attractive promos for visitors to the Pusur River tubing tour. As in the year-end promo where visitors will get a discounted price, namely tubing for 7 people, only 6 people will be charged. Then there are unique conditions, such as if 1 person can pass the slide challenge, then 3 people will not be charged.

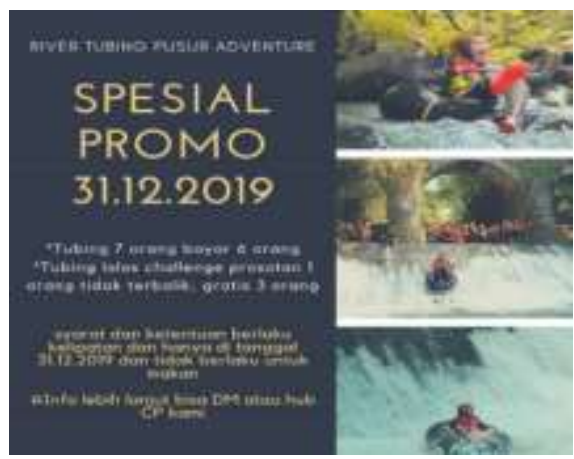

\section{Figure 1. Pamphlet of the River Tubing Pusur Tour Package}

Visitors who want to feel the sensation of tubing on the Pusur River can also pay for tourism fees by using garbage. Trash brought by visitors can be exchanged for money which can later be used as entrance tickets for tubing tours. Garbage from visitors will be deposited to the Waste Bank which will then be used as raw material for waste creation. aims to suppress waste disposal into the Pusur River and illegal landfills.

\section{c. Take action to clean the river to keep the river clean.}

Although Pusur River tubing tourism has developed and is able to attract many visitors, the RTPA and Watu Kapu communities have not forgotten their goal of always keeping the river clean. From an environmental perspective, there has been a change in community behavior, especially in treating rivers. People no longer throw their household waste directly into the river. Instead, they use the waste to be managed at the Waste Bank in order to get a sale value. For people who own cattle, there is also a change in behavior. They no longer throw cow dung directly into the river but instead use it into biogas as a substitute for LPG for cooking needs.

The presence of tubing tours also plays a very big role in inviting the community to treat the river well. In addition to serving tubing tours, the community also carries out routine river cleaning actions. The river cleanup actions include cleaning up trash, structuring river border areas such as building outbound arenas and parks, as well as structuring tubing paths so that visitors are guaranteed safety while traveling on the Pusur River. In addition, the community also has a position as an investigator if 
what is the potential for pollution in the Pusur river as a result of household or industrial activities. If this condition occurs, the community will submit recommendations to the authorities so that the best solution is found.

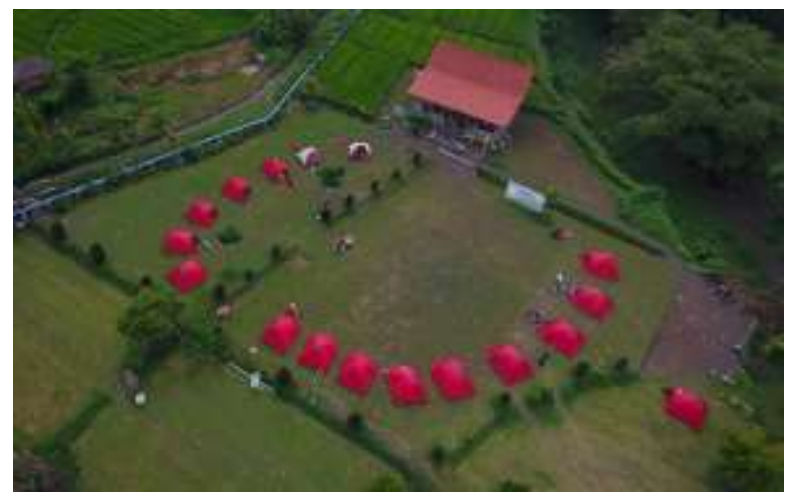

Figure 2. Construction of the Outbound Arena on the Pusur River Border

\subsection{Identify the social capital of the RTPA and Watu Kapu communities in the development of tubing tourism}

Robert Putnam defines social capital as that part of social life where there are networks, norms, and beliefs that encourage participants to act together more effectively to achieve common goals [16]. It can be said that social capital that grows in groups in a society can foster cooperation in a network that aims to achieve common goals. Social networks allow the emergence of coordination and communication that fosters mutual trust among community members. Trust can be seen from how people who are interrelated in a network have a mutual trust which will ultimately strengthen the norms regarding the necessity to help each other. Furthermore, social norms that will encourage the continuity of cooperation in the long term [17].

From this description, the author uses the theory of social capital according to Robert Putnam which sees social capital based on social networks, beliefs and social norms to see

\section{a. Participation in a network}

Through participation, it can be understood that social capital is not only built from individuals, but grows in a group to socialize as an inherently important part [18]. Participation in the development of tubing tourism can be seen from how the process of growing tubing tourism which was initially only managed by a community has now developed into 5 tubing tour managers. From here formed a community called River Tubing Pusur Adventure (RTPA) and Watu Kapu. In addition, in supporting efforts to optimize the management of the Pusur Sub-watershed from upstream, middle, and downstream, a community called the Pusur Institute was also formed. The presence of the Pusur Institute marks the formation of a new network as a connector for other networks owned by every actor 
who participates in the management of the Pusur Sub-watershed, including CSR PT Tirta Investama, NGOs, and the Polanharjo District Government.

\section{b. Trust}

Putnam emphasizes that social capital is a value of mutual trust [19]. The development of tubing tourism carried out by the RTPA and Watu Kapu communities has built trust between the community and tourism managers. This can be seen from the close voluntary relationship between the community and tubing tourism managers. The community is involved in the management of tubing tourism in terms of energy assistance when carrying out river cleaning actions and providing food as part of a tour package. This relationship exists on the basis of mutual trust and a sense of unity to develop Pusur River tubing tourism.

Trust can also be seen from the presence of the Pusur Institute as a forum for optimizing the management of the Pusur Sub-watershed. Pusur Institute members is communities in various fields such as tourism, agriculture, and waste banks on the basis of trust gather themselves in a Pusur Institute community to realize the integrated management of the Pusur Sub-watershed from upstream, middle, and downstream. The trust that exists shows the interaction in the development of tubing tourism and it can be seen that the presence of trust can affect the continuity of the development of Pusur River tubing tourism.

\section{c. Norm}

The presence of social norms has a role to control all behavior that refers to the rules that already exist in the community [18]. In tubing tourism development activities by the RTPA and Watu Kapu communities, the rules in tourism development are a commitment so that the development of Pusur River tubing tourism can run as planned and support the optimization of the management of the Pusur Sub-watershed. These rules include a prohibition on the public and tourists not to throw garbage around the river. This is done to always maintain the cleanliness of the Pusur River environment. Tourism procedures have also been regulated by the Standard Operating Procedures, one of which regulates the distribution of the number of visitors in each tour manager which aims to overcome so that tourist overload does not occur which will affect the safety of tourists.

\section{CONCLUTIONS}

Based on the findings of the data in the field, conclusions can be drawn, as follows:

a. The strategies of the RTPA and Watu Kapu communities in developing tubing tourism include building networks with NGOs, the government, companies, and communities along the Pusur sub-watershed; collaborate with the Pusur Institute as a community forum for the management of the Pusur sub-watershed; provide attractive tour packages; and take action to clean the river so that the cleanliness of the Pusur River is maintained; 
b. There is a mobilization of social capital in the development of the Pusur sub-watershed as a tubing tourism object and improving the community's economy. Social capital used in the development of tubing tourism is participation in a network, trust, and social norms. The social capital contained in the development of tubing tourism managed by the RTPA and Watu Kapu communities will determine the extent of the sustainability of the Pusur River tubing tour.

\section{REFERENCES}

[1] Purba, W.S, dkk, "Statistik Lingkungan Hidup Indonesia 2017”, Badan Pusat Statistik Indonesia, p. 7, 2017.

[2] Prakoso, A. A., "Arahan Pengembangan Kawasan Wisata Sungai Musi Kota Palembang", Jurnal Arsitektur dan Perencanaan (JUARA), 1(1), pp. 1-13, 2018.

[3] Tisnawati, E., \& Ratriningsih, D., "Pengembangan Konsep Pariwisata Sungai Berbasis Masyarakat; Studi Kasus: Kawasan Bantaran Sungai Gadjah Wong Yogyakarta”, Jurnal Arsitektur KOMPOSISI, 11(3), pp. 189-201, 2017.

[4] Aulia, A. N., \& Hakim, L, "Pengembangan Potensi Ekowisata Sungai Pekalen Atas, Desa Ranu Gedang, Kecamatan Tiris, Kabupaten Probolinggo", Jurnal Wilayah dan Lingkungan, 5(3), pp. 156$167,2017$.

[5] Mba, D.A, "Ekowisata Sebagai Bentuk Adaptasi Masyarakat Liang Ndara Pada Pariwisata", Jurnal Antropologi: Isu-Isu Sosial Budaya, 22(2), pp. 198-207, 2020.

[6] Badan Pusat Statistik Kabupaten Klaten, "Objek Wisata Menurut Kecamatann dan Jenisnya di Kabupaten Klaten Tahun 2017”, 7 Jan 2017. [Online] Available: https://klatenkab.bps.go.id/statictable/2019/01/17/286/pendapatan-pada-obyek-wisata-menurutkecamatan-dan-jenis-obyek-wisata-di-kabupaten-klaten-tahun-2017-000-rp-.html. [Accessed Jan 16, 2021].

[7] Fitriani, Eka., "Selain Umbul, Terdapat Wisata Susur Sungai dan Pemancingan di Kecamatan Polan Harjo", 23 July 2019. [Online] Available: https://solo.tribunnews.com/2019/07/23/selainumbul-terdapat-wisata-susur-sungai-dan-pemancingan-di-kecamatan-polanharjo-klaten?page=all.

[Accessed Jan 16, 2021].

[8] Afandi, M., Zakaria, R., Wardoyo, A., Kusumastuti, A., \& Saputro, R., "Pendekatan Integratif Dalam Pelestarian Sub Das Pusur Kabupaten Klaten”, Prosiding Seminar Nasional Geografi UMS IX 2018, pp. 349-361, 2018.

[9] Listy, Dinda Leo, "Sungai Pusur Klaten Dulu Jadi Tempat Sampah Sekarang Bawa Berkah", 15 May 2019. [Online] Available:https://travel.tempo.co/read/1205780/sungai-pusur-klaten-dulujadi-tempat-sampah-sekarang-bawa-berkah/full\&view=ok. [Accessed Jan 16, 2021].

[10] Suganda, E., Atmodiwirjo, P., \& Yatmo, Y. A., "Pengelolaan lingkungan dan kondisi masyarakat pada wilayah hilir sungai”. Hubs-Asia, 10(1), pp. 144-153, 2011.

[11] Ulum, M. C. \& Ngindana, R., Environmental Governance: Isu Kebijakan dan Tata Kelola Lingkungan Hidup, Malang, UB Press, 2017. 
Vol. 4, Issue.6, Nov-Dec 2021, p no. 336-346

[12] Afrizal, M. A., Metode Penelitian Kualitatif Sebagai Upaya Mendukung Penggunaan Penelitian Kualitatif Dalam Berbagai Disiplin Ilmu, Jakarta Rajawali Press, 2015.

[13] Sugiono.,Metode Penelitian Pendidikan (Pendekatan Kuantitatif, Kualitatif, dan R\&D), Bandung, Alfabeta, 2010.

[14] Wijayanti, R., Baiquni, M., \& Harini, R., "Strategi penghidupan berkelanjutan masyarakat berbasis aset di Sub DAS Pusur, DAS Bengawan Solo", Jurnal Wilayah dan Lingkungan, 4(2), pp. 133-152, 2016.

[15] Amalyah, R., Hamid, D., \& Hakim, L., "Peran Stakeholder Pariwisata dalam Pengembangan Pulau Samalona Sebagai Sestinasi Wisata Bahari”, Jurnal Administrasi Bisnis, 37(1), pp. 158-163, 2016.

[16] Field. J., Modal Sosial, Yogyakarta, Kreasi Wacana, 2016.

[17] Syahra, R, "Modal sosial: Konsep dan Aplikasi”, Jurnal Masyarakat dan Budaya, 5(1), pp. 122, 2003.

[18] Febriani, L., \& Saputra, P. P., "Modal Sosial Dalam Pengembangan Madu Kelulut Sebagai Komoditas Ekonomi Dan Pariwisata Di Kecamatan Lubuk Kabupaten Bangka Tengah”, Society, 6(2), pp. 83-91, 2018.

[19] Alfianti, D., Solikatun, S., \& Rahmawati, R.," Modal Sosial Dalam Pengembangan Ekowisata di Desa Marente Kecamatan Alas Kabupaten Sumbawa", RESIPROKAL: Jurnal Riset Sosiologi Progresif Aktual, 3(1), pp. 120-132, 2021.

\section{Author Profile}

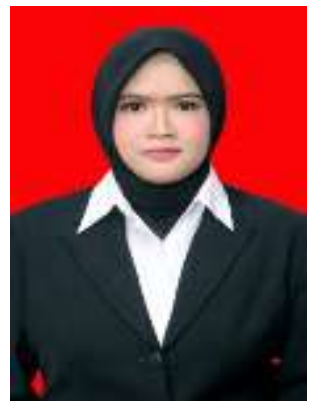

Yuanita Dwi Hapsari received S.Pd degree in Faculty of Teaching and Education Science from Sebelas Maret University in 2018 Surakarta, Indonesia. She is currently pursuing a postgraduate in Department of Sociology in Faculty of Social and Political Science from Sebelas Maret University, Indonesia. She has expertise in environmental sociology, disaster sociology, and gender. The current domicile is in Klaten Regency, Central Java Province, Indonesia. 